\title{
GEODETIC DEFORMATION ACROSS THE CENTRAL APENNINES FROM GPS DATA IN THE TIME SPAN 1999-2003
}

\author{
Marco Anzidei ${ }^{(1)}$, Paolo Baldi ${ }^{(2)}$, Arianna Pesci ${ }^{(1)}$, Alessandra Esposito ${ }^{(1)}$, Alessandro \\ Galvani $^{(1)}$, Fabiana Loddo ${ }^{(1)}$ and Paolo Cristofoletti ${ }^{(1)}$ \\ ${ }^{(1)}$ Istituto Nazionale di Geofisica e Vulcanologia, Rome, Italy \\ ${ }^{(2)}$ Università di Bologna, Dipartimento di Fisica, Bologna, Italy
}

\begin{abstract}
During the time span 1999-2003 was set up and repeatedly surveyed a not permanent GPS network located across one of the highest seismic areas of the central Apennines (Italy). The Central Apennine Geodetic Network (CA-GeoNet), extends across Umbria, Abruzzo, Marche and Lazio regions, in an area of $\sim 180 \times 130 \mathrm{~km}$, from Tyrrhenian to the Adriatic sea. It consists in 125 GPS stations distributed at $3-5 \mathrm{~km}$ average grid and includes 7 permanent GPS stations operated by the Italian Space Agency (ASI) and the Istituto Nazionale di Geofisica and Vulcanologia (INGV).

With the aim to estimate the active strain rate across this part of the chain, the GPS sites have been located on the main geological units of the area and across the typical basin and range structures, related with the main seismogenic faults.

In this paper we show the network and the first results obtained for a subset of 23 stations that have been occupied at least during three repeated campaigns, in the time span 19992003. Data analysis, performed by Bernese 4.2 software, shows an extensional rate normal to the chain, in agreement with geological and seismic data. The strain rates in the inner chain are ranging from $12 \times 10^{-9} \pm 11 \mathrm{yr}^{-1}$ to $16 \times 10^{-9} \pm 11 \mathrm{yr}^{-1}$ and from $-14 \times 10^{-9} \pm 11 \mathrm{yr}^{-1}$ to $-3 \times 10^{-9} \pm 11 \mathrm{yr}^{-1}$. This result provides an improved estimation of the ongoing deformation of this area with respect to previous studies and is in agreement with the style of deformation inferred from seismicity and with the features of the main seismogenic sources from recent geological and seismological investigations.
\end{abstract}

\section{Introduction}

The development of geodetic space techniques and particularly of the NAVSTAR Global Positioning System (GPS), yelded to the realization of high precision geodetic networks devoted to geodynamic investigations in areas interested by recent active tectonics. This technique is able to define the relative positioning of the observation sites located on the Earth's surface within centimetric precision even for baselines of hundreds of kilometers and without the limitation of the terrestrial techniques, such as the mutual visibility between the observation sites. This enables us to study a new classes of tectonic processes both at regional and local scale, which previously were difficult to approach with the conventional geodetic techniques. On these basis, we set up a new GPS geodetic network across an intensely faulted area of Central Apennine (Central Italy), designed to measure the detailed pattern of the current crustal deformations. During the last 25 years, several geological, seimological and geodetic studies have been performed in the central Apennines, to assess the seismic hazard of this region (Bosi et al., 1975; Amato et al., 1992; Amato et al., 1993; Galadini and Messina, 1993; Blumetti et al., 1993; Blumetti et al., 1996; Ghisetti eVezzani, 1996; Pantosti et al., 1996; Amato et al., 1998; Calamita et al., 1999; Calamita et al., 1994a,b; Basili et al., 1999; Boschi et al., 1998; Boschi et al., 1999; Galadini and Galli, 2000; Barchi et al., 2000; Peruzza, 1999). Anyway this sector of the chain has never been investigated in detail through a tailor made GPS geodetic network devoted to an 
accurate estimation of the ongoing crustal deformation of this region. For this reason was planned and set up the Central Apennine Geodetic Network (CA-GeoNet), with mean distances between stations at 3-5 kilometres and capable to estimate the sub regional and near field strain rates across the main seismogenic structures and faults, which are supposed to drive the crustal dynamics of this area.

\section{Geological and structural setting}

The Apennines formed since the end of Miocene and developed in a chain-foredeepforeland dynamic system. They are characterized by the overlying of several mesozoic and cenozoic paleogeographic domains, NE migrating (Bigi et al., 1990; Calamita et al., 1999) (Fig.1). Since Miocene the Central Apennines displayed several tectonic phases and the geological units of the Umbria-Marche area were bended and thrusted on those of the laziale-abruzzese carbonatic platform. The latter have been subsequently thrusted on the Marche- Abruzzo formations. All these structures defines a thrust edifice NW-SE trending, with N-S dextral and WNW-ESE left lateral strike slip systems (Alfonsi et al., 1991; Catalano et al., 1993; Mattei, 1995; Corrado et al., 1997), as evidenced by independent geophysical data (Speranza et al., 1997).

Since upper Pliocene and lower Pleistocene, the Apennines underwent to an extensional tectonic phase that produced NW-SE trending normal faults (Bigi et al., 1990; Calamita et al., 1999; Calamita et al., 1994a,b). The combined action of the Plio-quaternary faults produced several intermontane basins, filled with continental deposits. These basins are of great importance for the assessment of the Quaternary tectonics because the largest earthquakes and active tectonics are located within these zones (Bosi et al., 1975; Lavecchia et al., 1994; Boschi et al., 1995; Cello et al., 1997; Calamita et al., 1999; Boschi et al., 1999; Galadini e Galli, 2000; Galadini e Messina, 2001; Valensise and Pantosti, 2001).

The Umbria - Marche area, displays Mesozoic and Cenozoic formations (limestones with silica and marls) NE-ward bended and thrusted, with axis ranging from NW-SE to NNE-SSW in the northern and southern sectors, respectively. The Quaternary faults downlifted SW-ward trending blocks, (Calamita et al., 1999) and the sedimentary basins (Fig.2). The Lazio - Abruzzo sector, which consists in Mesozoic and Cenozoic cabonatic units NW-SE thrusted with E-W trending planes (Accordi e Carbone, 1988; Ghisetti e Vezzani, 1990), during Quaternary experienced extensional tectonics that produced normal faults (Ghisetti e Vezzani, 1996). Active faults, with geological slip rates up to $\sim 1 \mathrm{~mm} / \mathrm{yr}$ (Barchi et al., 2000; Valensise and Pantosti, 2001; Galadini e Galli, 2000) have been identified in this area. High angle faults systems, NW-SE striking, are located in the external sector of the Apennine chain (Southern Laga, Sibillini and Gran Sasso Mts.) and produced differential lowering toward SE. Active faults border the Quaternary basins of Amatrice and Campotosto (Bigi et al., 1990; Barchi et al., 2000; Valensise and Pantosti, 2001; Galadini e Galli, 2000).

\section{Seismicity}

The seismicity of the Central Apennines, known by historical information and modern instrumental recordings, shows maximum magnitudes at 7.1 and macroseismic intensities up to XI MCS scale (Postpischl, 1985; Westaway, 1992; Boschi et al., 1995; Boschi et al., 1998; Boschi et al., 1999) (Fig.2). Among the largest earthquakes that struck this region during the last two millennia, the 1703 seismic sequence is the most remarkable. Although the spatial and temporal evolution of this sequence is still a debated matter, the main shocks occurred in a wide area between Norcia and L'Aquila with intensities up to XI MCS and produced large damages and casualties. Finally, in 
1915, the Fucino area was subjected to a M=7.1 (XI MCS) destructive seismic event, with epicentral location near Avezzano (Boschi et al., 1995).

In recent times, from crustal and subcrustal earthquakes, Amato and Selvaggi (1992), defined three main seismogenetic belts in the central Apennines: the first running along the western margin (Tyrrhenian), with earthquake hypocentres $<7 \mathrm{~km}$ and high geothermal gradients; the second within the chain, with extensional mechanisms and hypocentres between 5 and $15 \mathrm{~km}$; the last, which is the less active and release minor energy, borders the Adriatic sea and displays compressive and strike slip earthquakes. The maximum seismic energy is released in the inner part of the chain, along a belt NNW-SSE striking and 50-60km width. It is worth nothing that in the Umbria-Marche region, deep earthquakes have been located up to $90 \mathrm{~km}$ depth, supporting the hypothesis of a subducting adriatic litosphere under peninsular Italy. This seems in agreement with seismic tomography data, although a lack of deep seismicity in the other sectors of the central Apennines prevented to extrapolate this interpretation to the whole chain (Amato et al., 1993; Spakman, 1990). The instrumental seismicity recorded during the time span 1982-2003 (Fig.3a), is mainly located in the UmbriaMarche area and along the Olevano - Antrodoco - Posta structural lineament (Salvini e Vittori, 1982). The former is addressed to the Umbria - Marche 1997 seismic sequence, while the the latter is located along the border between the regional tectonic structures of the Umbria-Marche-Sabina in the West and of the Gran Sasso in the East (Fig.1). The available focal mechanisms of the largest earthquakes occurred in the 1939-1980 time span (Gasparini et al., 1985) and the seismic sequences of Norcia, in 1979 (Deschamps et al., 1984), Lazio - Abruzzo, in 1984 (Westaway et al., 1989) and Colfiorito, in 1997 (Amato et al., 1998), show a general extensional tectonic regime, with T axis NE-SW trending (Frepoli and Amato, 1997; Montone et al., 1997). After these earthquakes, the region was subjected only to a few low energy seismic events, especially during the time span 1999-2003 (Fig.3b), the same epochs of the GPS surveys.

\section{The Ca-Geonet and GPS campaigns}

The CA-GeoNet, established in 1999 and completed in 2001, consists in 124 GPS stations, distributed with an average grid at 3-5 km (Anzidei et al., 2003). Siting was performed taking into account the geological and structural features of the region, and the geodetic benchmarks have been located on significant outcropping units. The largest part of the GPS stations are located across the Plio-quaternary basins and the main seismogenic sources, inferred from geological and seismological data (Valensise and Pantosti, 2001) (Fig.4).

We used 3-D type GPS monuments for the 125 not permanent stations. The network includes 7 permanent GPS stations managed by the Italian Space Agency (AQUI, CAME, UNPG) and by the Istituto Nazionale di Geofisica and Vulcanologia (INGR, VVLO, RSTO, INGP).

During the time span 1999-2003 all the stations of the network have been occupied and 23 of them have been repeatedly measured during at least three campaigns. We used Trimble 4000SSi dual frequency receivers, equipped with Trimble L1/L2 Ground Plane geodetic antenna (22020-00 type). Surveys have been rigorously planned taking into account network grid, number of station to be measured simultaneously (up to 11), and time required to move receivers through the network. Each station has been occupied for an average observation window of 48 hours, for at least two survey session per station. GPS data were collected at $30 \mathrm{sec}$. sample rate during each observation session of at least 12 to 24 hours duration. To constrain the daily solutions and to include the 
network in a unique reference frame, we used data collected at permanent stations (CAME, UNPG, AQUI, RSTO, INGR, VVLO and INGP); moreover for the whole campaign duration, TERM and PRET stations continuously operated as semipermanent stations.

\section{GPS data processing, velocity field and strain analysis}

The GPS data have been processed by means of the Bernese 4.2 software, performing the following steps: generation of satellite orbits using precise ephemeredes from CODE (Center of Orbit Determination); computation of the best value for point positions from code pseudo-range observables and receiver clocks correction; creation of undifferenced phase data from receiver carrier phase readings; creation of single difference phase data and computation of their correlations; coordinate estimation from triple-differences processing and cycle slips detection; computation of the doubledifference solution solving for baseline components and real phase ambiguity values; integer ambiguity values estimation (iterative procedure); computation of the fixed bias solution starting from previous estimates, adopting different acceptance or rejection criteria. The strategy used for baselines computation (step 3) was based on network geometry and station distribution, taking into account measurement sessions. Single difference daily observations were formed between the available fiducial stations, continuously operating during the campaign, to the other CAGeoNet stations. The tropospheric zenith delay was computed and corrected using the standard Saastmoinen model and estimating a set of time-dependent parameters for each site. The elevationdependent antenna phase center corrections were applied, according to the IGS_1 model. The ionospheric effect was reduced introducing the estimation of the global TEC (Total Electronic Content) obtained by the L4 (geometry-free) linear combination analysis . The ambiguities were computed adopting the wide-lane technique. In the first step, the linear combination L5 was processed and the wide-lane ambiguities were stored; in the second, the L3 (iono-free) combination was used, the wide-lane ambiguities were introduced as known and the narrow-lane ambiguities were solved.

Daily solutions were computed and combined for each campaign by a least-square sequential adjustment and finally combined (Koch, 1988). A free network solution approach was adopted to avoid 'distorsions' (Brockmann and Gurtner, 1996).

In table 1 are listed the root mean square values of daily solutions with respect to the adjusted values for each campaign, providing the repeatability of the North, East and Up components. To estimate velocities at the CAGeoNet stations, we combined the normal equations solutions of the four campaigns, adding new station parameters: coordinates at reference epochs and mean velocities (Tab.2). Fig. 6 shows the time series for the North and East components of 23 stations of the network. Values are referred to INGR station. The strain rate estimation was performed by a least square adjustment under the uniform field condition, using station velocities as observables.

$$
\left(\begin{array}{cccccc}
1 & 0 & \Delta x_{1} & \Delta y_{1} & 0 & 0 \\
0 & 1 & 0 & 0 & \Delta x_{1} & \Delta y_{1} \\
\vdots & \vdots & \vdots & \vdots & \vdots & \vdots \\
1 & 0 & \Delta x_{1} & \Delta y_{1} & 0 & 0 \\
0 & 1 & 0 & 0 & \Delta x_{1} & \Delta y_{1}
\end{array}\right)\left(\begin{array}{c}
U \\
V \\
L_{11} \\
L_{12} \\
L_{21} \\
L_{22}
\end{array}\right)=\left(\begin{array}{c}
u_{1} \\
v_{1} \\
\vdots \\
u_{n} \\
v_{n}
\end{array}\right)
$$

The velocity gradient tensor was computed and its strain and rotational parts separated. Eigenvalues were obtained from matrix diagonalization, providing strain rate values along the two principal axis $\left(E_{\max }, E_{\min }\right)$ and the orientation (azimuth $\varphi$ ). 


$$
\begin{aligned}
& E_{\text {max }}=\left(L_{11}+L_{22}+\sqrt{\left(L_{11}-L_{22}\right)^{2}+\left(L_{12}+L_{21}\right)^{2}}\right) / 2 \\
& E_{\text {min }}=\left(L_{11}+L_{22}-\sqrt{\left(L_{11}-L_{22}\right)^{2}+\left(L_{12}+L_{21}\right)^{2}}\right) / 2 \\
& \varphi=\frac{1}{2} \operatorname{arctg}\left(-\frac{L_{12}+L_{21}}{L_{11}-L_{22}}\right)
\end{aligned}
$$

The procedure was applied to different data set, as shown in figure 7, using as fiducial stations AQUI, CAME, INGR, PRET, RSTO, TERM, UNPG and VVLO stations.

Our results show an extensional behaviour of the chain, in agreement with geological and seismic data, and a significant compression in its inner part. Strain rates are ranging from $12 \times 10^{-9} \pm 11 \mathrm{yr}^{-1}$ to $16 \times 10^{-9} \pm 11 \mathrm{yr}^{-1}$ and from $-14 \times 10^{-9} \pm 11 \mathrm{yr}^{-1}$ to $-3 \times 10^{-9} \pm 11 \mathrm{yr}^{-1}$, normal and along the chain axis, respectively.

The computed deformation trend represents a significant improvement of earlier results published in previous papers by D'Agostino et al. (2001) from the reoccupation of part of the IGM95 network (Surace, 1993; 1997), by Serpelloni et al. (2001) and Anzidei et al. (2001) from the Tyrgeonet and GeoModAp networks, by Hunstad and England (1999) and Hunstad et al. (2003) from historical IGM triangulation network. These previous geodetic studies estimate maximum strain rates for the Central Apennines at $180 \pm 30 \times 10^{-9}$ (D’Agostino et al. 2001), $57 \pm 13 \times 10^{-9}$ (Caporali et al., 2003), from $3.7 \pm 29 \times 10^{-9}$ to $116 \pm 32 \times 10^{-9}$ (Hunstad et al., 2003), $4.1 \pm 0.8 \times 10^{-9}$ (Ward, 1994), $31 \pm 8 \times 10^{-9}$ (Serpelloni et al., 2002), generally higher but with similar strikes with respect to those shown in this paper. The different time span used in the data, the available data set, the network size, geometry and finally the number of stations analysed, can be partially responsible of such differences in the obtained results.

\section{Conclusions}

Our data provide a more detailed view on the present-day sub-regional and near deformation field of this region, thanks to the high number of stations and the short baselines $(3-5 \mathrm{~km})$ among stations. The striking of the strain axes show that the area is undergoing to an active deformation with NE-SW prevailing extension, normal to the chain. No relevant seismic activity occurred in the last years in the surveyed area, even if the region experienced destructive earthquakes in the past.

Moreover if the post-seismic deformations related with the last largest earthquakes (Fucino, 1915, Ms=6.9 and Umbria-Marche, 1997, Ms=5.9), located in the southernmost and northernmost sides of the network respectively, are ended or weak and confined within a few $\mathrm{km}$ across the fault (Aoudia et al., 2003), the observed deformation is interseismic, thus describing the regional and purely elastic deformation field of the region. The extensional behaviour of the area, normal to the chain, is in agreement with the distribution and trend of the main seismogenic sources reported in Valensise and Pantosti (2001) that could play a major role in the observed deformations and in the kinematic of the peninsular Italy.

New surveys, planned in 2004 to add new velocity data, will improve the knowledge of the active strain rate estimation in this high risk seismic area.

The local deformation field, that can be representative of the accumulating deformation on the faults, will allow to estimate the present day slip rate related with the single faults or structures and to distinguish their temporal and spatial variations from repeated surveys. The network grid at $3-5 \mathrm{~km}$, which is optimal with respect to the average seismogenic fault size of the central Apennines, will allow to obtain affordable geodetic 
data to constrain eventual coseimic dislocation models. Finally the combination with DinSAR data will provide an accurate spatial deformation pattern of this region, related with seismic cycle (Massonnet D. et al., 1993; Massonnet et al., 1996), as recently performed in the Apennines during the 1997 Umbria-Marche earthquakes 1997 (Hustad et al., 1998; Anzidei et al., 1999; Stramondo et al., 1999; Salvi et al., 2000).

\section{Ackowledgments}

This reasearch has been performed under the Italian Space Agency Project Applicazione delle tecniche spaziali per la valutazione del campo di deformazione crostale e della pericolosita 'sismica dell'Appennino centro meridionale. We are thankful to Prof. Enzo Boschi who encouraged this work, Dr. Paolo Marsan, of the National Seismic Service who made available the occupation of the Aquilano Geodetic Network, Dr. Andrea Tertulliani for the helpful scientific discussion on the historical seismicity. A special thanks to Mr. Sergio Del Mese and Angelo Massuci for their valuable collaboration during site reconoissance and field surveys.

\section{References}

Alfonsi L., R. Funiciello, and M. Mattei (1991): Strike-slip tectonics in the Sabina area. Boll. Soc. Geol. It. 110, 481-488.

Amato A. and G. Selvaggi G. (1992): Terremoti crostali e subcrostali nell'Appennino settentrionale. Studi Geologici Camerti, vol. spec. 1991/1, 75-82.

Amato A., Alessandrini B., Cimini G.B., Frepoli A. and Selvaggi G. (1993): Active and remnant subducted slabs beneath Italy: evidence from seismic tomography and seismicity, Ann. Geofis., 36, 201-214.

Amato A., Azzara R., Chiarabba C., Cimini G.B., Cocco M., Di Bona M., Margheriti L., Mazza S., Mele F., Selvaggi G., Basili A., Boschi E., Courboulex F., Deschamps A., Gaffet S., Bittarelli G., Chiaraluce L., Piccinini D. \& Ripepe M. (1998) - The 1997 Umbria-Marche, Italy, earthquake sequence: a first look at the main shocks and aftershocks. Geophys. Res. Lett., 25, NO.15, 2861-2864.

Anzidei M., Baldi P., Galvani A., Pesci A., Hunstad I. and E.Boschi (1999): Coseismic displacement of the 26th september 1997 Umbria - Marche (Italy) earthquakes detected by GPS: campaigns and data. Annali di Geofisica, vol.42, n.4, 597-607

Anzidei M., Baldi P., Casula G., Galvani A., Mantovani E., Pesci A., Riguzzi F., Serpelloni E. (2001): Insights on present-day crustal motion in the Central Mediterranean area from GPS surveys. Geophysical Journal International, vol. 146, 98-110

Anzidei, M., Galvani, A., Esposito, A., Cristofoletti, P., Pesci, A., Baldi, P., Casula., G., Cenni, N., Loddo, F., Serpelloni, E. (2003): The Central Apennine Geodetic Network (CA-Geonet): description and preliminary results, Geophysical Research Abstracts, XXVIII European Geophysical Society General Assembly, Vol. 5, Abstract EAE03-A05288 . 
Aoudia A., A. Borghi, R. Riva, R. Barzaghi, B. A. C. Ambrosius, R. Sabadini, L. L. A. Vermeersen and G. F. Panza (2003). Postseismic deformation following the 1997 Umbria-Marche (Italy) moderate normal faulting earthquakes. Geoph. Res. Lett., Vol. 30, 7, 1390 .

Barchi M., Galadini F., Lavecchia G., Messina P., Michettti A.M., Peruzza L., Pizzi A., Tondi E., e Vittori E. (2000). Sintesi delle conoscenze sulle faglie attive in Italia centrale: parametrizzazione ai fini della caratterizzazione dela pericolosità sismica. CNR - Gruppo Nazionale per la Difesa dai terremoti - Roma, 62pp.

Basili R., Galadini F. e Messina P. (1999). The applicatiion of palaeolandsurface analysis to the study of recent tectonics in central Italy. In Uplift, Erosion and Stability: perspectives on long-term landscape development, a curu by Smith, B.J., Whalley W. B., \& Warke P. A.. Geological Society, London Special pubblications, 162, 109-117.

Bigi G., Cosentino D., Partotto M., Sartori R. e Scandone P. (1990). Structural model of Italy (scala 1:500.000) sheet n.4. CNR-PFG.

Boschi E., Ferrari G., Gasperini P., Guidoboni E., Smriglio G. \& Valensise G. (1995) Catalogo dei forti terremoti in Italia dal 461 a.C. al1980. Istituto Nazionale di Geofisica (ING) e Storia Geofisica Ambiente (SGA).

Boschi E., Guidoboni E., Ferrari G., Valensise G. (1998): I terremoti dell'Appennino Umbro-Marchigiano. Area sud orientale dal 99 a.C. al 1984. Istituto Nazionale di Geofisica, SGA Storia Geofisica Ambiente. 267 pp.

Boschi E., Gasperini P., Valensise G., camassi R., Castelli V., Stucchi M., Rebez A., Monachesi G., Barbano M.S., Albini P., Guidoboni E., Ferrari G., Mariotti D., Comassi A., Molin D. (1999): Catalogo parametrico dei terremoti italiani. Editrice Compositori

Bosi C. (1975). Osservazioni preliminari su faglie probabilmente attive nell'Appennino centrale. Boll. Soc. Geol. It. 94, 827-859, 28 ff., 1 tav..

Blumetti A.M., Cavinato G.P. e Tallini M. (1996). Evoluzione plio-quaternaria della conca di L'Aquila-Scoppito: studio preliminare. Il Quaternario, 9 (1), 281-286.

Blumetti A.M., Dramis F. e Michetti A.M. (1993). Fault-generated mountain fronts in the central Apennines (central Italy): geomorphological features and seismotectonic implications. Earth Surface Processes and landforms, 18, 203-223

Brockmann, E., and W. Gurtner (1996), Combination of GPS Solutions for Densification of European Network: Concepts and Results Derived from 5 European Associated Analysis Centers of the IGS, in EUREF workshop, Ankara, May 1996.

Calamita F., Coltorti M., Pieruccini P. e Pizzi A. (1999). Evoluzione strutturale e morfogenesi plio-quaternaria dell'Appennino umbro-marchigiano tra il preappennino umbro e la costa adriatica. Boll. Soc. Geol. It. 118, 125-139,6 ff.

Calamita F., Cello G., Deiana G. \& Paltrinieri W. (1994a) - Structural styles, chronology rates of deformation, and time-space relationships in the Umbria-Marche thrust system (central Apennines, Italy). Tectonics, 13, 873-881. 
Calamita F., Coltorti M., Farabollini P. \& Pizzi A. (1994b) - Le faglie normali quaternarie nella Dorsale appenninica umbro-marchigiana. Proposta di un modello di tettonica d'inversione. Stud. Geol. Camerti. Vol. Spec., 1994, 211-225.

Caporali A., Martin S., Massironi M. (2003) Average strain rate in the Italian crust inferred from a permanent GPS network - II. Strain rate versus seismicity and structural geology. Geophys. Journal International, 155, 254-268

D'Agostino N., Giuliani R., Mattone M., and Bonci L. (2001) Active crustal extension in the central Apennines (Italy) inferred from GPS measurements in the interval 19941999. Geophys. Res. Lett., 28,10,2121-2124

Deschamps A., Iannaccone G. \& Scarpa R. (1984) - The Umbrian earthquake (Italy) of 19 September 1979, Ann. Geophys., 2, 29-36.

Frepoli A. \& A. Amato (1997) - Contemporaneous extension and compression in the North Apennines from earthquake fault plane solutions, Geophys. J. Int., 129, 368-388.

Gasparini C., Iannaccone G. \& Scarpa R. (1985) - Fault-plane solutions and seismicity of the Italian Peninsula, Tectonophysics, 117, 59-78

Galadini F. e Galli P. (2000). Active tectonics in the central Apennines (Italy) -input data for seismic hazard assessment. Natural Hazard 22, 225-270.

Galadini F. e Messina P. (1993). Stratigrafia dei depositi continentali, tettonica ed evoluzione geologica quaternaria dell'Alta Valle del fiume Sangro (Abruzzo meridionale). Boll. Soc. Geol. It. 112, 877-892, 10 ff., 1 tav. f.t..

Ghisetti F. e Vezzani L. (1996). Geometrie deformative ed evoluzione cinematica dell'Appennino centrale. Studi Geol. Camerti. XIV, 127-154.

Ghisetti F. e Vezzani L. (1990). Stili strutturali nei sistemi di sovrascorrimento dellacatena del Gran sasso (Appennino centrale) . Studi Geol. Camerti. Vol. spec., 3750 .

Hunstad I., Anzidei M., Baldi P. Cocco M., Galvani A., Pesci A. (1998): Modelling Coseismic displacements during the 1997 Umbria-Marche earthquake (Central Italy). Geoph. Jou. Int., 139, 283-295

Hunstad I. and P. England (1999): An upper bound on the rate of strain in the central Apennines, Italy, from triangulation measurements between 1869 and 1963. Earth and Planetary Science Letters, 169, 261-267.

Hunstad I., Selvaggi G., D'Agostino N., England P., Clarke P. and Pierozzi M. (2003): Geodetic strain in peninsular Italy between 1875 and 2001 Geophysical Research Letters, 30, (4), 1181.

Koch, K.R. (1988), Parameter estimation and hypotesis testing in linear models, Springer, Berlin Heidelberg New York. 
Mazzoli S., Corrado S., De Donatis M., Scrocca D., Butler D.W.H., Di Bucci D., Naso G., Nicolai C. e Zucconi V. (1997). Time and space variability of the "thin-skinned" and "thick-skinned" thrust tectonics in the Apennines (Italy). Rend. Fis. Acc. Lincei s. 9, v. 11, 5-39

Montone P., Amato A., Frepoli A., Mariucci M.T. \& Cesaro M. (1997) - Crustal stress regime in Italy. Ann. di Geofis., 40, 3, 741-757.

Pantosti D., D’Addezio G., e Cinti F.R. (1996). Paleoseismicity of the Ovindoli-Pezza fault, central Apennines, Italy: a history including a large, previously unrecord earthquake in the Middle Ages (860-1300 A.D.). J. Geophys. Res. 101, 5937-5959.

Peruzza L. (1999): Progetto MISHA. Metodi innovativi per la stima dell'hazard: applicazione all'Italia centrale. CNR-Gruppo Nazionale per la Difesa dei Terremoti, Roma, 176 pp.

Postpischl D. (1985) - Catalogo dei terremoti italiani dall'anno 1000 al 1980. Quaderni de "La Ricerca Scientifica", CNR-PFG, 114, vol. 2B, Roma.

Salvi S., S. Stramondo, M. Cocco, E. Sansosti, I. Hunstad, M. Anzidei, P. Briole, P. Baldi, M. Tesauro, E. Lanari, F. Doumaz, A. Galvani, A. Pesci (2000): MODELling COSEISMIC DISPLACEMENT RESULTING FROM SAR INTERFEROMETRY AND GPS MEASUREMENTS DURING THE 1997 UMBRIA - MARCHE SEISMIC SEQUENCE Journal of Seismology,4, 479-499

Salvini F. \& Vittori E. (1982) - Analisi strutturale della linea Olevano-Antrodoco-Posta (Ancona-Anzio Auct): metodologie di studio delle deformazioni fragili e presentazione del tratto meridionale. Mem. Soc. Geol. It., 24, 337-355.

Serpelloni E., Anzidei M., Baldi P., Casula G., Galvani A., Pesci A., Riguzzi F. (2001): Geodetic measurement of crustal deformations in central-southern Apennines (Italy). Annali di Geofisica, vol.44, n.3, 627-647

Serpelloni E., Anzidei M., Baldi P., Casula G., Galvani A., Pesci A. \& Riguzzi F.(2002): Combination of permanent and non-permanent GPS networks for the evaluation of the strain-rate field in the central Mediterranean area. Bollettino di Geofisica Teorica ed Applicata, Vol.43, n.3-4, 195-219

Spakman W. (1990) - Tomographic images of the upper mantle below central Europe and the Mediterranean, Terra Nova, 2, 542-553.

Stramondo S., Tesauro M., Briole P., Sansosti E., Salvi S., Lanari R., Anzidei M., Baldi P., Fornaro G., Avallone A., Buongiorno M.F., Franceschetti G., Boschi E.(1999): The September 26,1997 Central Italy earthquakes: coseismic surface displacement detected by sar interferometry and GPS, and fault modeling. Geophysical Research Letters, vol.26, n. 7, pp.883-886

Surace L. (1993): Il progetto IGM95. Bollettino di Geodesia e Scienze Affini 3, 220-230

Surace L. (1997): La nuova rete geodetica nazionale IGM95: risultati e prospettive di utilizzazione. Bollettino di Geodesia e Scienze Affini 3, 357-377 
Valensise L. and Pantosti D. (2001): Database of Potential Sources For Earthquakes Larger Than M=5.5 in Italy. Annali di Geofisica, vol.44, suppl.1, with CD-ROM

Ward S.N. (1994): Constraints on the seismotectonics of the Central Mediterranean sea from Very Long Baseline Interferometry . Geohys. Jour. International, 117, 441-452. Wells and Coppersmith (1994): New empirical relationships among magnitude, rupture length, rupture width and surface displacements. Bullettin of Sesmological Society of America, 84 (4), 974-1002.

Westaway R., Gawthorpe R. \& Tozzi M. (1989) - Seismological and field observations of the 1984 Lazio-Abruzzo earthquakes: implications for the active tectonics of Italy, Geophys. J. R. astr. Soc., 98, 489-514.

Westaway R. (1992) - Seismic moment summation for historical earthquakes in Italy: tectonic implication. Jour. of Geophys. Res., 97, B11, 15437-15464. 


\section{FIGURE CAPTIONS}

Fig.1 Geological and structural sketch of the central Apennines (modified from Mazzoli et al., 1997; Cello et al., 1997).

Fig. 2 Historical seismicity of the central Appennine from 179 B.C. to 1979 and Intensities $\geq$ VIII MCS (from Boschi et al., 1995; Boshi et al., 1998; Boschi et al.,1999).

Fig.3 Instrumental seismicity during the time span a) 1986-2003 and b) 1999-2003 (Ml>3.0 from the INGV Seismic Bullettin).

Fig.4 Distribution of the CA-GeoNet stations with respect to the seimogenetic sources, as reported in Valensise and Pantosti (2001).

Fig.5 Sketch of the CA-GeoNet occupations during the repeated campaigns performed in the time span 1999-2003: a) distribution of measured station for each campaign; b) state of the art: blue circles display the stations measured at least three times between 1999 and 2003.

Fig. 6 Horizontal GPS position time series, for the North (N), East (E) components with respect to INGR station.

Fig. 7 Velocity (black arrows) and strain (double blue and red arrow) fields, estimated during the time span 1999-2003, after four repeated campaigns (red dots permanent stations and green dots non permanent stations). Max strain is at $16 \times 10^{-9} \pm 11 \mathrm{yr}^{-1}$; min strain is at $-14 \times 10^{-9} \pm 11 \mathrm{yr}^{-1}$. Seismogenic sources from Valensise and Pantosti (2001). 


\section{TABLE CAPTIONS}

Table 1 Root mean values of the daily solutions with respect to the adjusted values of each campaign.

Tab 2 GPS site velocities ( $\mathrm{mm} / \mathrm{yr}$ ) and related errors at 95\% confidence level, computed with respect to the continuous monitoring INGR station. Data estimated after four repeated campaigns (1999-2003). 


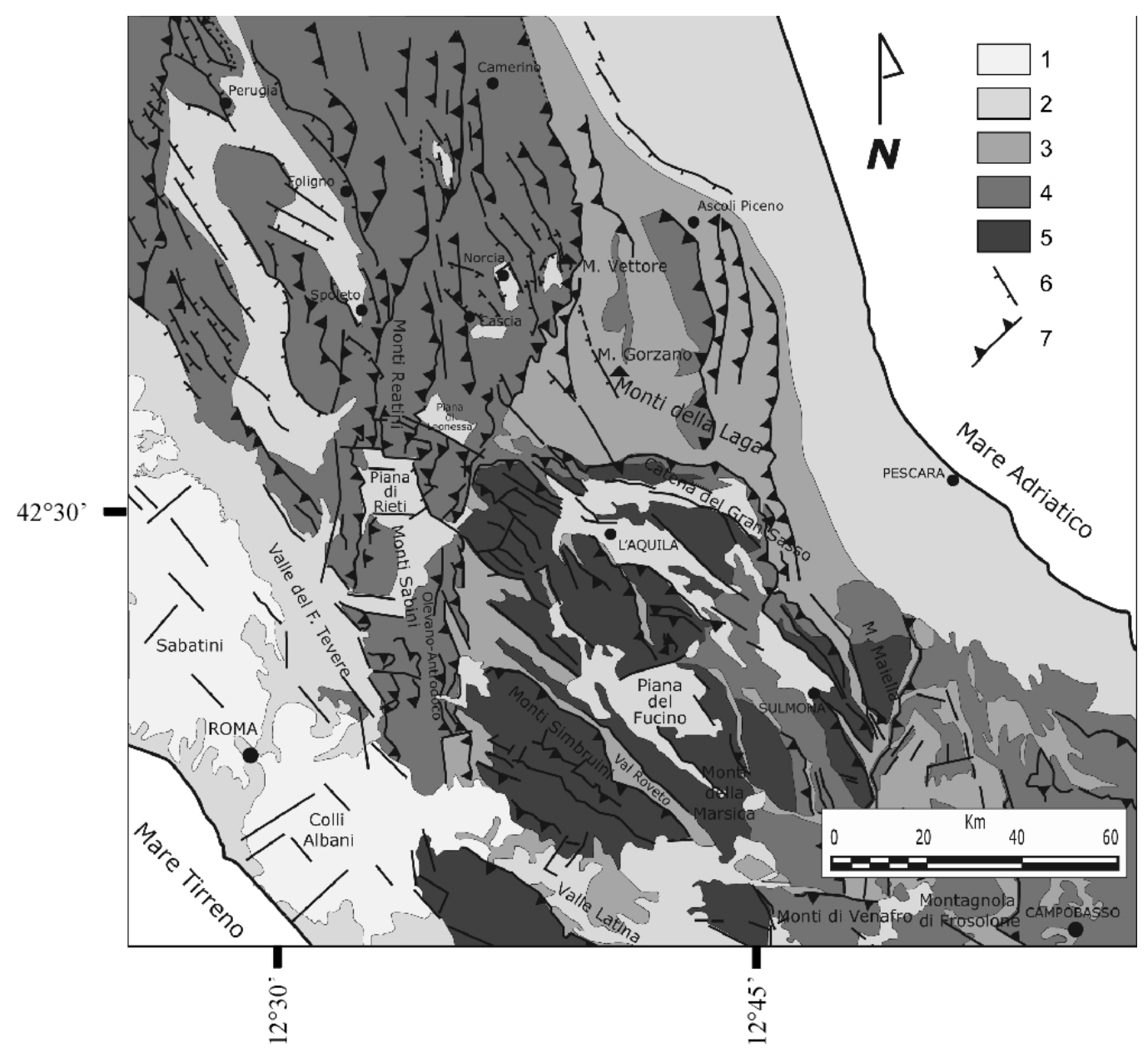

FIG. 1 


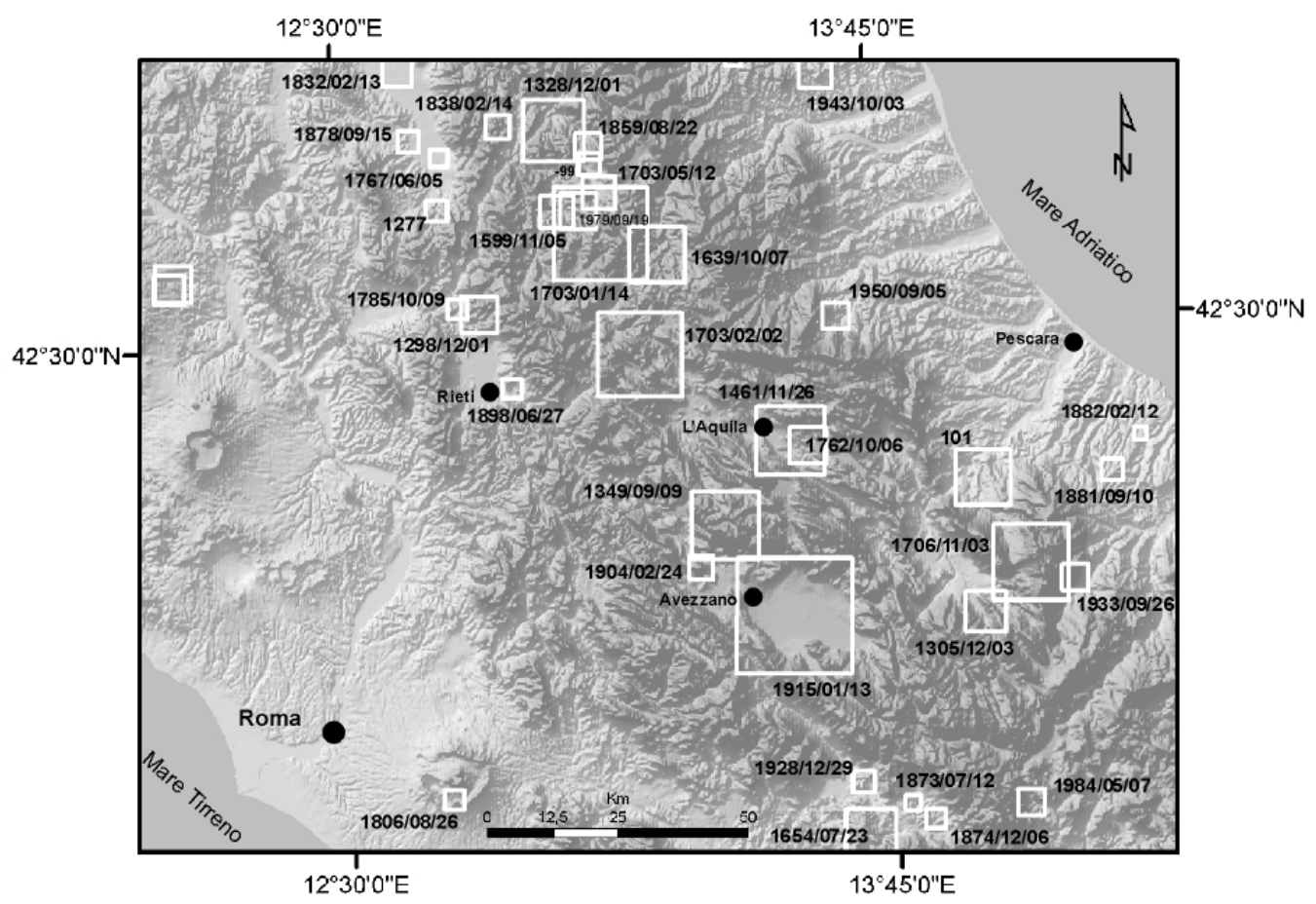

FIG.2 


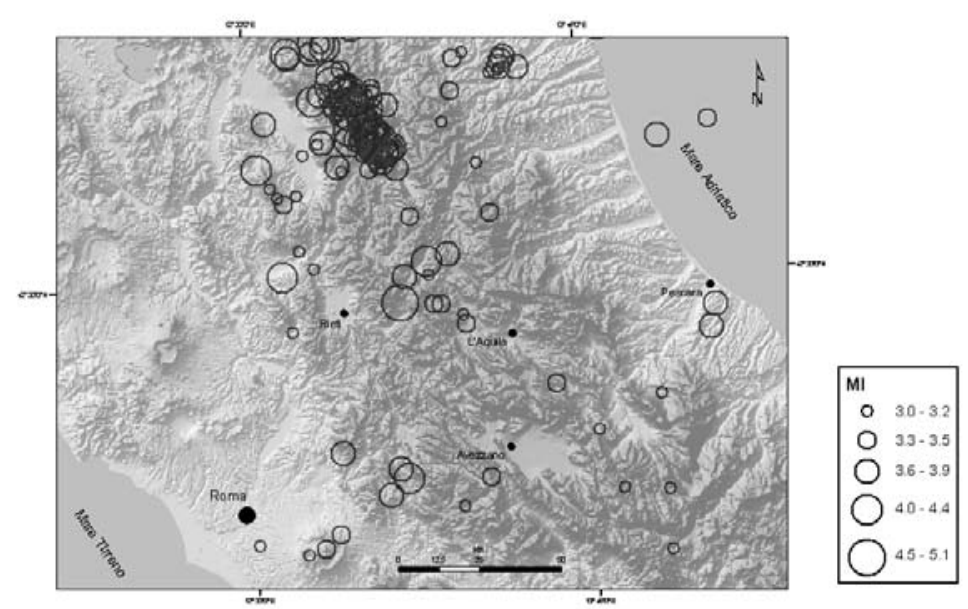

a

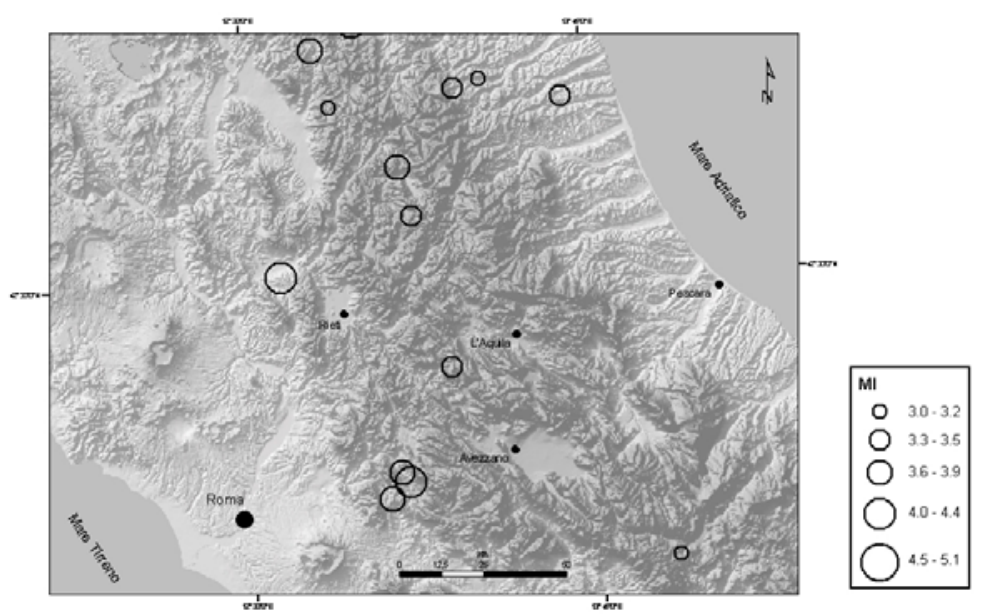

b

FIG. 3 


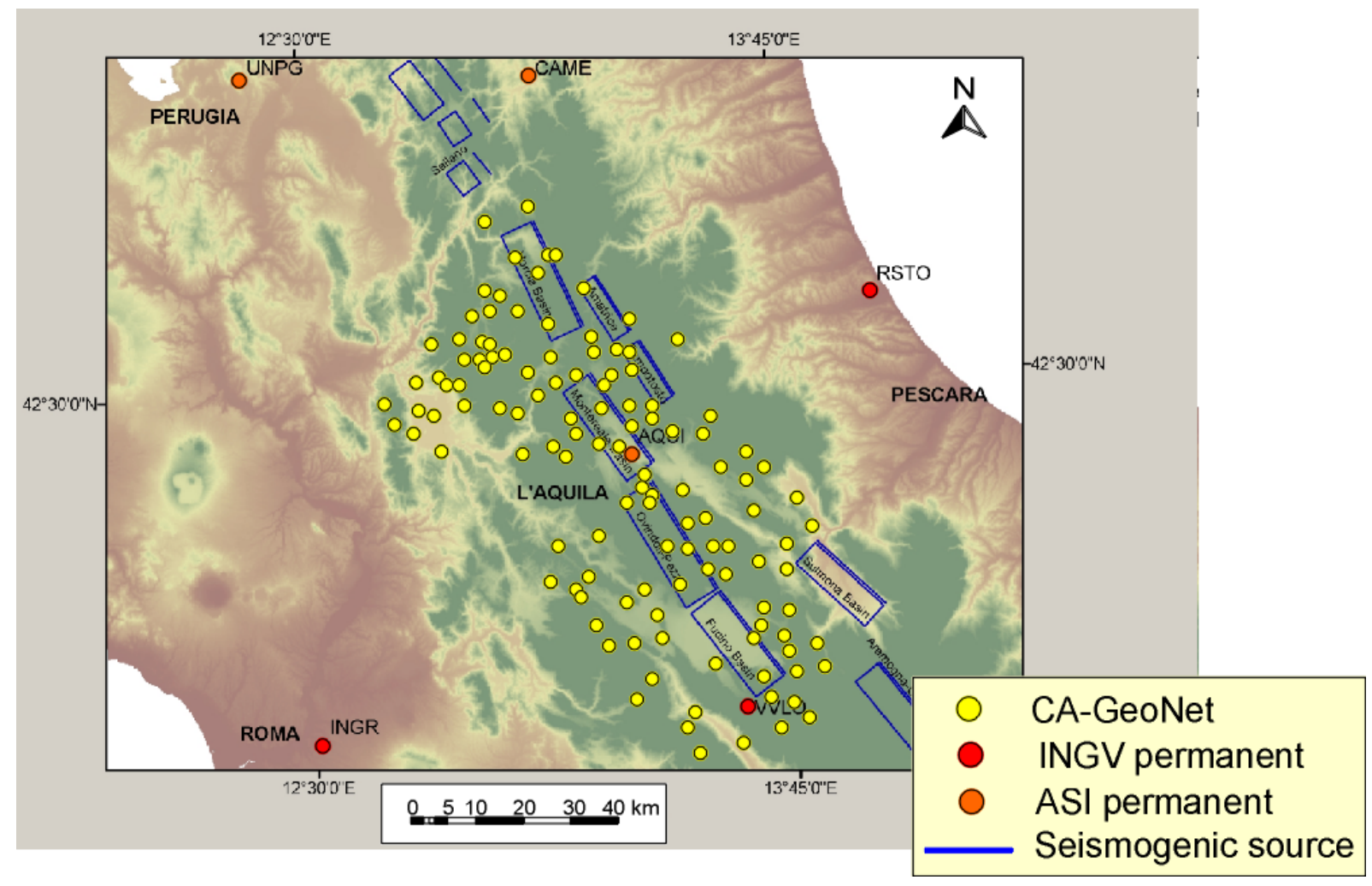

FIG.4 

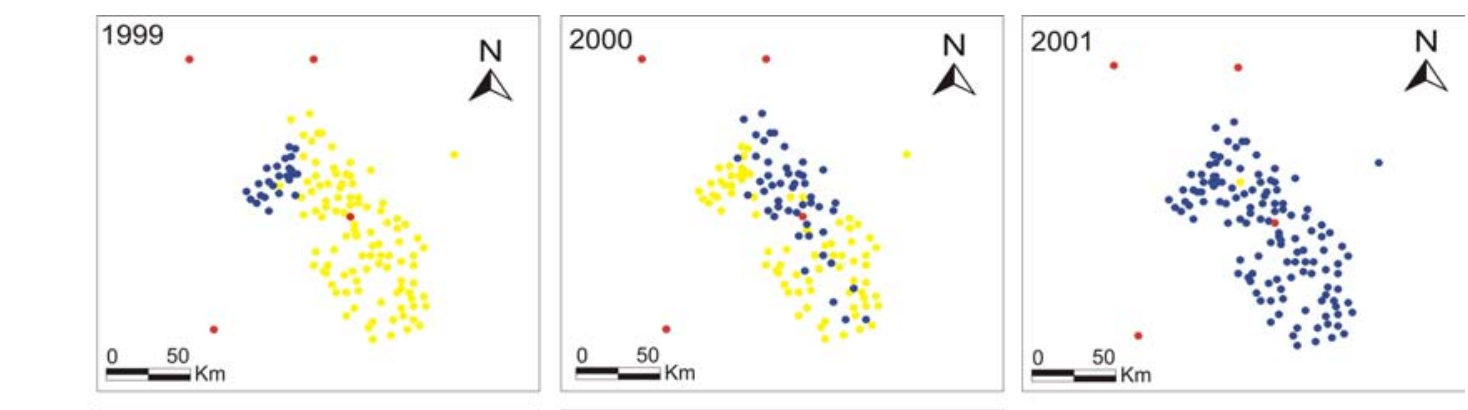

a)
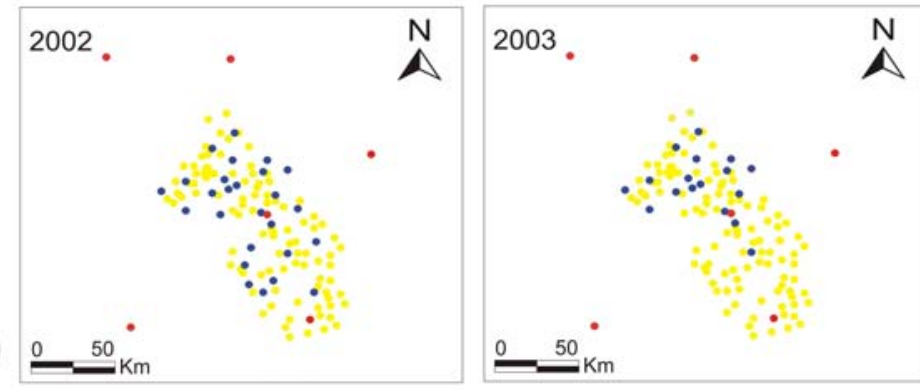

- measured stations

- permanent stations not measured

b)

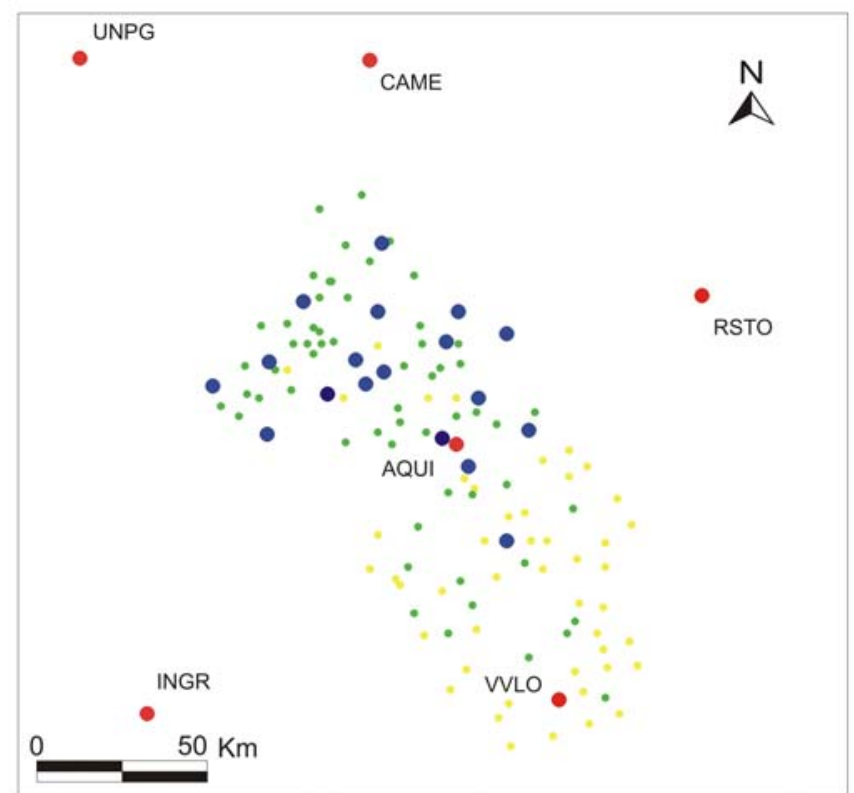

- stations measured 4 times between 1999 and 2003

stations measured 2 times between 1999 and 2002

- permanent stations only 1 measurement

FIG.5 

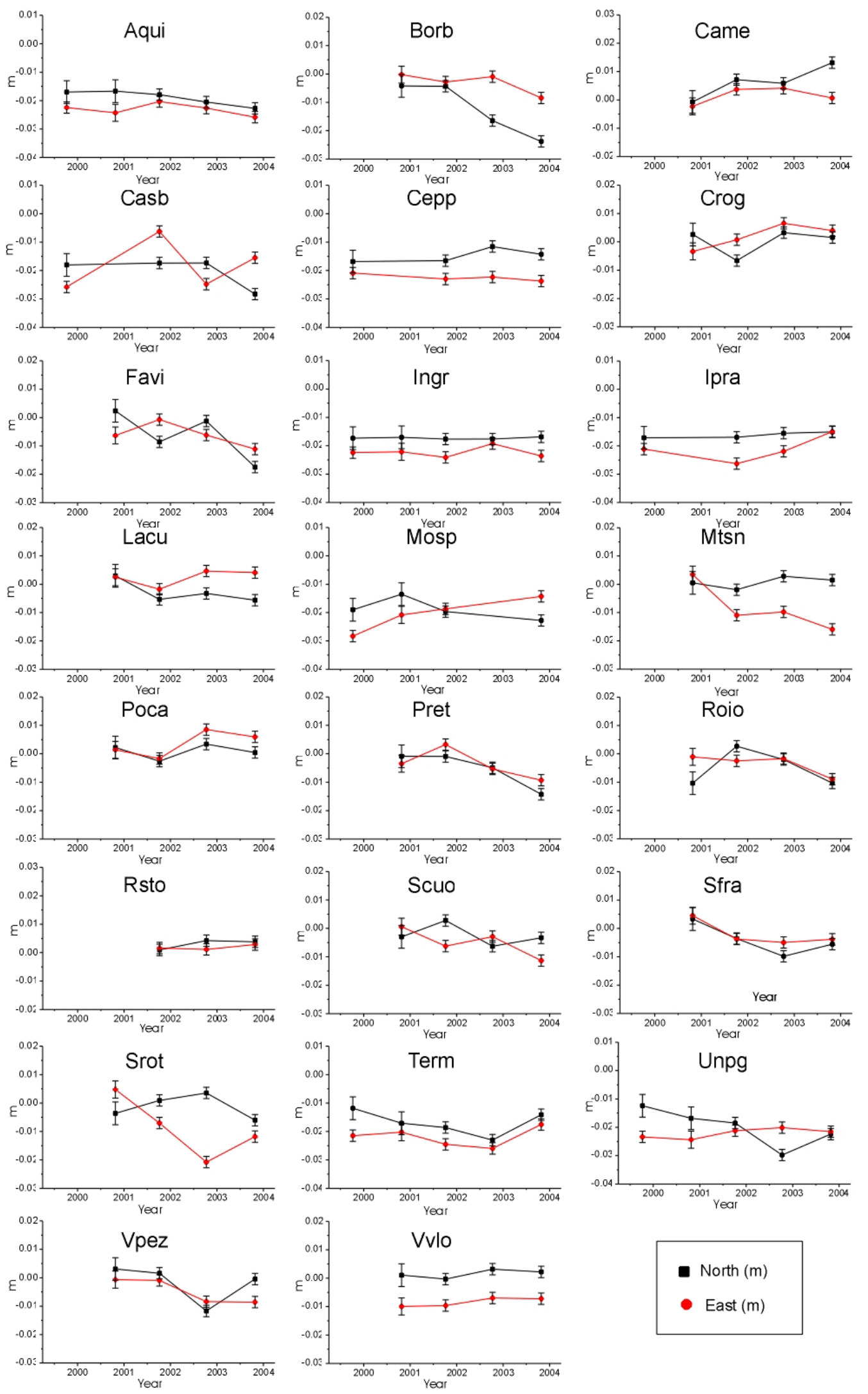

- North $(\mathrm{m})$

- East (m)

\section{FIG.6}



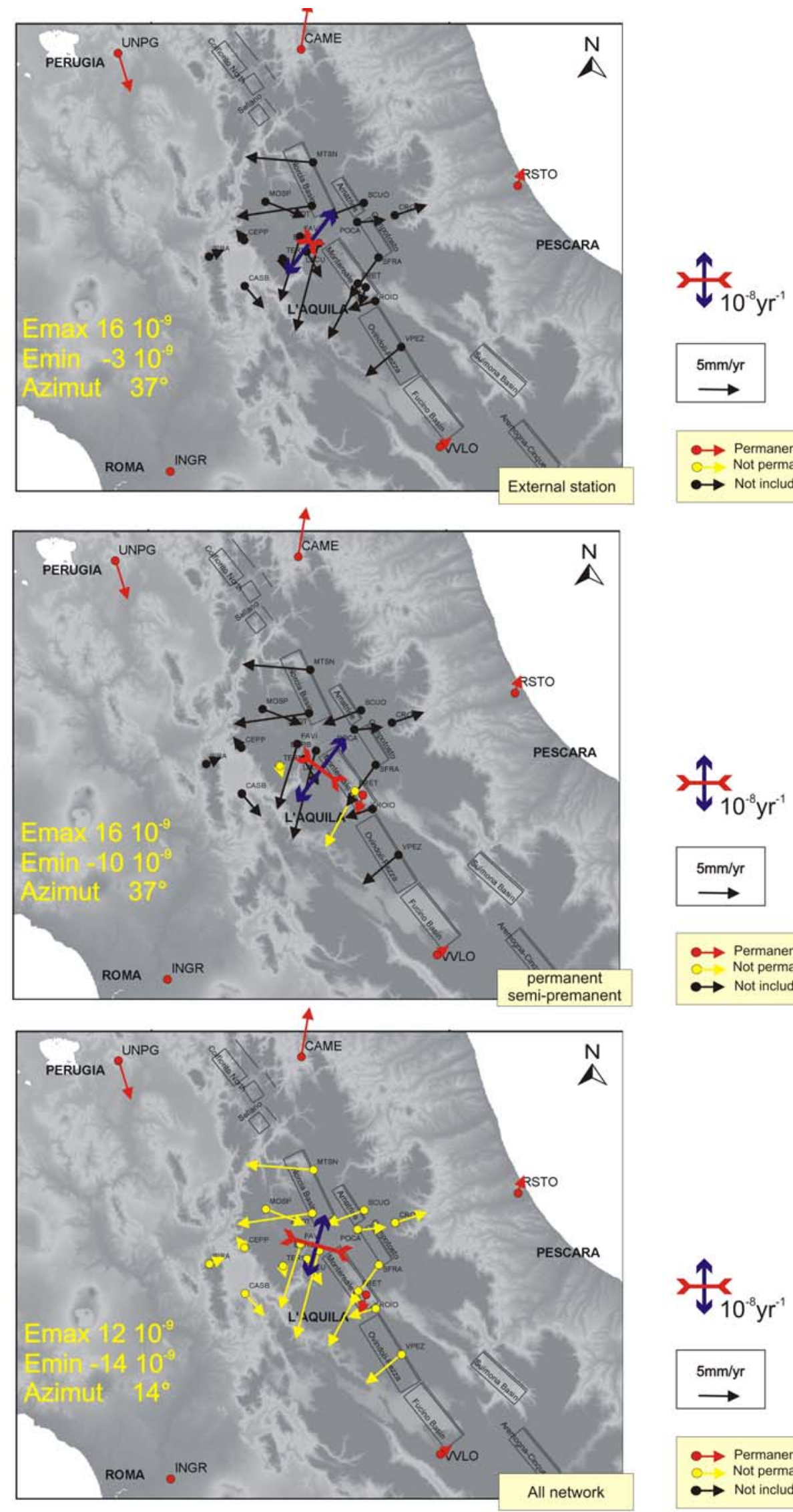

$5 \mathrm{~mm} / \mathrm{yr}$

$\rightarrow$ Permanent station

- Not permanent station

$\longrightarrow$ Not included station

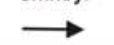

$\longrightarrow$ Permanent station

$\rightarrow$ Not permanent station

$\rightarrow$ Not included station

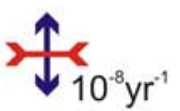

$5 \mathrm{~mm} / \mathrm{yr}$

$\longrightarrow$ Permanent station $\rightarrow$ Not permanent station $\rightarrow$ Not included station

FIG.7 


\begin{tabular}{|c|c|c|c|}
\hline year & $\begin{array}{c}\text { North } \\
(\mathbf{m m})\end{array}$ & $\begin{array}{c}\text { East } \\
(\mathbf{m m})\end{array}$ & $\begin{array}{c}\boldsymbol{U p} \\
(\mathbf{m m})\end{array}$ \\
\hline 1999 & 2.1 & 3.5 & 7.8 \\
\hline 2000 & 2.7 & 3.5 & 5.9 \\
\hline 2001 & 2.0 & 1.6 & 7.1 \\
\hline 2002 & 2.1 & 1.6 & 7.7 \\
\hline 2003 & 2.2 & 2.2 & 8.0 \\
\hline
\end{tabular}

Table 1 


\begin{tabular}{c|c|ccc|ccc}
\hline \multicolumn{1}{c}{ CaGeoNet relative velocity field respect to INGR station } \\
\hline Num & Station & \multicolumn{3}{|c|}{$\begin{array}{c}\mathrm{V}_{\mathrm{E}} \\
(\mathrm{mm} / \mathrm{yr})\end{array}$} & \multicolumn{3}{c}{$\begin{array}{c}\mathrm{V}_{\mathrm{N}} \\
(\mathrm{mm} / \mathrm{yr})\end{array}$} \\
\hline 4 & AQUI & -1.7 & \pm & 0.3 & -0.9 & \pm & 0.3 \\
10 & BORB & -7.9 & \pm & 0.9 & -2.1 & \pm & 0.7 \\
14 & CAME & 4.1 & \pm & 0.4 & 1.4 & \pm & 0.3 \\
18 & CASB & -2.3 & \pm & 0.7 & 0.8 & \pm & 0.5 \\
21 & CEPP & 1.3 & \pm & 0.5 & -1.0 & \pm & 0.4 \\
32 & CROG & 0.9 & \pm & 0.7 & 1.8 & \pm & 0.6 \\
39 & FAVI & -4.4 & \pm & 0.7 & -4.0 & \pm & 0.5 \\
46 & INGR & 0.0 & \pm & 0.2 & 0.0 & \pm & 0.2 \\
47 & IPRA & 0.7 & \pm & 0.5 & 0.6 & \pm & 0.4 \\
49 & LACU & -2.3 & \pm & 0.6 & 1.3 & \pm & 0.5 \\
60 & MOSP & -2.0 & \pm & 0.7 & 2.2 & \pm & 0.5 \\
64 & MTSN & 0.6 & \pm & 0.8 & -6.1 & \pm & 0.6 \\
76 & POCA & 0.3 & \pm & 0.6 & 2.3 & \pm & 0.5 \\
80 & PRET & -2.8 & \pm & 0.4 & -0.8 & \pm & 0.4 \\
90 & ROFA & -0.9 & \pm & 2.1 & 5.0 & \pm & 1.6 \\
91 & ROIO & -2.0 & \pm & 0.7 & -2.4 & \pm & 0.6 \\
96 & SCUO & -1.7 & \pm & 0.7 & -4.1 & \pm & 0.5 \\
100 & SFRA & -3.0 & \pm & 0.7 & -2.3 & \pm & 0.6 \\
108 & SROT & 0.0 & \pm & 0.8 & -8.2 & \pm & 0.6 \\
115 & TERM & -1.2 & \pm & 0.3 & -0.8 & \pm & 0.3 \\
126 & VPEZ & -2.7 & \pm & 0.6 & -4.2 & \pm & 0.5 \\
129 & VVLO & 1.2 & \pm & 0.3 & 0.5 & \pm & 0.3 \\
131 & RSTO & 1.5 & \pm & 0.5 & 0.0 & \pm & 0.4 \\
303 & UNPG & -4.0 & \pm & 0.4 & 0.4 & \pm & 0.2 \\
& & & & & & &
\end{tabular}

TAB. 2 